\title{
Predictors of poor obstetric outcome among women with chronic kidney disease: A five-year observational study.
}

\author{
Osama Elkilani*1, Wael Gaber'1, Haitham Hamza', Mahmoud Emara ${ }^{2}$, Hassan Badr ${ }^{3}$, Sameh Abd- \\ Allah $^{3}$ \\ ${ }^{1}$ Department of Obstetrics and Gynecology, Faculty of Medicine, Menoufia University, Egypt. \\ ${ }^{2}$ Department of Internal Medicine, Faculty of Medicine, Menoufia University, Egypt. \\ ${ }^{3}$ Department of Pediatrics, Faculty of Medicine, Menoufia University, Egypt.
}

\begin{abstract}
Objective: To assess prospectively the maternal and fetal outcome among pregnant women with chronic kidney disease (CKD) compared to normal control group to find out predictors of poor obstetric outcome.

Methods: A prospective observational study conducted on 490 pregnant women with CKD who were divided into two groups according to K-DOQI guidelines, group $1(\mathrm{n}=286$, stage-1 CKD) and group 2 $(n=204$, stages 2-4 CKD) with a third group of normal pregnant women $(n=200)$. Obstetric outcome was recorded. Univariate and multivariate regression analysis was used to assess the association between poor obstetric outcome and maternal risk factors.

Results: Patients with CKD were more prone to experience poor maternal and fetal outcome compared to control group $(p<0.001)$. Stage of $C K D \geq 2(O R=2.33, C I=1.26-3.96)$, duration of $C K D \geq$ 5 years $(O R=0.69, C I=0.53-0.98)$, baseline creatinine $1.5-3 \mathrm{mg} / \mathrm{dl}(\mathrm{OR}=2.14, \mathrm{CI}=1.34-3.44)$, baseline creatinine $>3 \mathrm{Mg} / \mathrm{dL}(\mathrm{OR}=\mathbf{2 . 2 8}, \mathrm{CI}=1.17-4.05)$, pelvicalyceal dilatation on renal ultrasound $(\mathrm{OR}=1.49$, $\mathrm{CI}=1.22-2.85)$, initial Hypertension $(\mathrm{OR}=4.11, \mathrm{CI}=1.71-9.85)$, intake of more than two antihypertensive drugs $(\mathrm{OR}=1.75, \mathrm{CI}=1.28-3.88)$, antenatal care visits $<6 \quad(\mathrm{OR}=1.99, \mathrm{CI}=1.45-2.76)$, initial proteinuria $(\mathrm{OR}=\mathbf{2 . 2 3}, \mathrm{CI}=1.99-2.89)$, development of preeclampsia $(\mathrm{OR}=1.66, \mathrm{CI}=1.11-3.21)$, the presence of prenatal anemia $(\mathrm{OR}=0.14, \mathrm{CI}=\mathbf{0 . 0 2 - 0 . 2 5})$ and the presence of underlying systemic disease $(\mathrm{OR}=3.08, \mathrm{CI}=2.04-4.65)$ were strong predictors of poor obstetric outcome in patients with $\mathrm{CKD}$.

Conclusions: Patients with CKD even those in the early stage suffered from poor maternal and fetal outcome. Many risk factors other than hypertension, proteinuria and underlying systemic disease were identified as predictors of poor obstetric outcome.
\end{abstract}

Keywords: Chronic kidney disease, Obstetric outcome, Maternal outcome, Fetal outcome.

Accepted on January 12, 2018

\section{Introduction}

Chronic kidney disease (CKD) is characterized by late clinical manifestations when glomerular filteration rate (GFR) drops below $25 \%$ of normal with creatinine rise after loss of more than $50 \%$ of the renal function [1].

Several studies reported poor maternal outcome in the form of development of hypertension, proteinuria, cesarean delivery and recurrent urinary tract infection as well as poor fetal outcome in the form of prematurity, low birth weight and perinatal mortality in women with CKD [2-6].

From early pregnancy, increased renal blood flow leads to an increase in GFR of more than $50 \%$ accompanied by a relative decrease in concentrations of serum urea and creatinine. Women with CKD are less able to make the renal adaptations needed for a healthy pregnancy [4].

Most of the studies were retrospective with only reporting of obstetric outcome rather than emphasis on the predictors of poor outcome.
The aim of this study was to assess prospectively the maternal and fetal outcome in women with CKD compared to normal control group to find out predictors of poor obstetric outcome.

\section{Materials and Methods}

This was a prospective observational study conducted on pregnant women with chronic kidney disease (CKD) in comparison to normal control group, in the period between the beginnings of October 2012 and October 2017 at the department of Obstetrics and Gynecology in collaboration with the Neonatology unit of the Pediatrics department and Nephrology unit of the Internal Medicine department at Menoufia University hospital, Shibin El-Kom city, Menoufia governorate, Egypt.

The ethical committee at the Menoufia Faculty of Medicine formally reviewed and approved the study protocol. All participants signed the informed consent form in accordance with the World Medical Association Declaration of Helsinki. 
Citation: Elkilani O, Gaber W, Hamza H, et al.. Predictors of poor obstetric outcome among women with chronic kidney disease: A five-year observational study.. J Preg Neonatal Med 2018;2(1):5-9.

Based on the rate of adverse pregnancy outcome of two- to three folds in patients with CKD from the literature, a sample size of 200 participants was needed in every group in order to achieve a power of $80 \%$ at the 0.05 significance level.

Among pregnant women attending the antenatal care outpatient clinic or referred from other hospitals, in the first trimester (between 6-12 weeks gestation), during the study period, 370 patients were diagnosed to have CKD on the initial visit, based on the results of estimated glomerular filteration rate (eGFR) according to K-DOQI guidelines. Patients were then subdivided into two groups; early stage CKD (stage-1) and late stage CKD (stages 2-4 as no pregnant patients with stage-5 attended our hospital) with enrollment of a third group of pregnant normal control of 206 pregnant women (normal kidney functions tests initially and at the beginning of the third trimester) for comparison. 286 patients in the early stage group, 204 patients in the late stage group and 200 women in the control group completed the study (Figure 1).

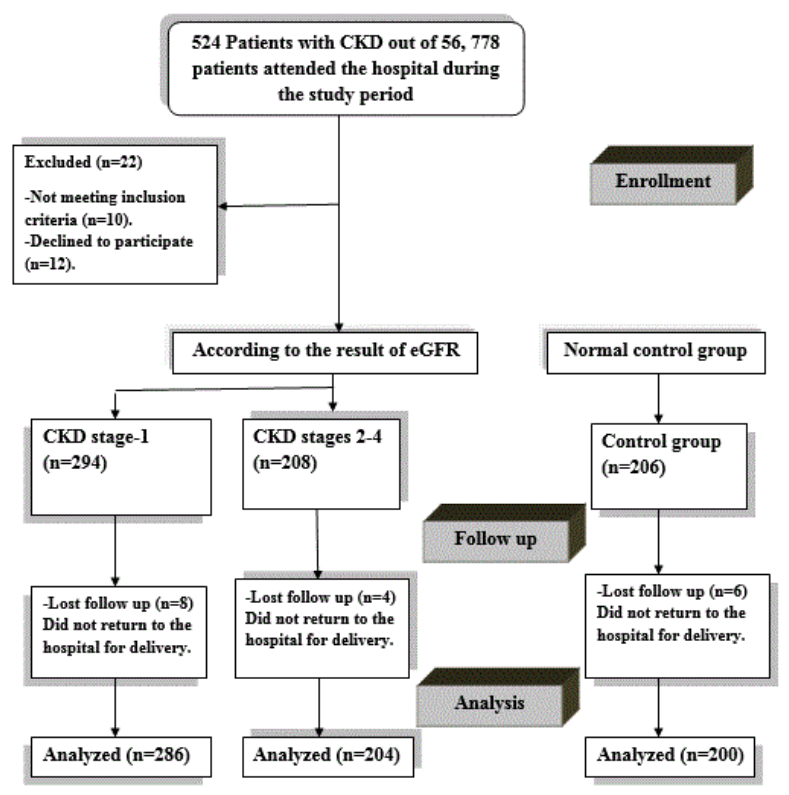

Figure 1. The flow diagram.

Patients with any other associated medical disorders as bronchial asthma or epilepsy as well as pregnant women with multiple pregnancy or congenital fetal malformations were excluded from the study.

All enrolled women underwent thorough history taking, clinical examination and laboratory testing on the basis of regular antenatal care units every 2-4 weeks to be seen every visit by Obstetrician and Nephrologist till delivery.

The local hospital protocol for management of patients with CKD entails -Regular blood pressure measurement with administration of antihypertensive drugs (chiefly methyl dopa and nifedipine) to keep the blood pressure at less than 120/70 mmHg. -Administration of low dose aspirin 75-81 mg per day from the 12th week until delivery. -Urine analysis: to rule out infection, proteinuria and hematuria to be performed every 2-4 weeks depending on the stage of CKD.

-Renal function tests: urea, creatinine and estimated glomerular filteration rate (eGFR) depending on the stage of CKD with more frequent examinations in the second half of pregnancy.

-Full blood count every trimester with supplementation of iron and erythropoietin as indicated to keep $\mathrm{Hb}>11 \mathrm{gm} \%$.

- Baseline renal ultrasound at booking (around 12 weeks gestation) for pelvi-caliceal dimensions to be repeated in the presence of symptoms suggesting obstruction.

\section{Outcome measures}

-Maternal outcome: Deterioration of kidney function based on urea, creatinine and eGFR, miscarriage (bleeding in early pregnancy $<20$ weeks), antepartum hemorrhage (bleeding in late pregnancy $>20$ weeks), development of gestational hypertension (elevation of the systolic blood pressure $\geq 140$ $\mathrm{mmHg}$ and/or the diastolic blood pressure $\geq 90 \mathrm{mmHg}$ on two occasions within 4 hours apart), anemia (Hb concentration $<11$ gm\%), development of preeclampsia (a new onset proteinuria with $0.3 \mathrm{~g}$ of protein or more in a 24-hour specimen after 20 weeks gestation with the presence of hypertension), number of hospital admissions for medical or obstetric reasons, mode of delivery, postpartum hemorrhage, antenatal or postpartum blood transfusion, admission to intensive care unit (ICU) and maternal mortality.

-Fetal and neonatal outcome: intrauterine fetal demise, low birth weight (newborn weight $<2.5 \mathrm{Kg}$ ), prematurity (delivery before 37 weeks), low Apgar score less than 7 at 5 minutes, admission to neonatal intensive care unit (NICU), need for assisted ventilation and neonatal mortality (death during the first 4 weeks after delivery).

- Predictors of poor obstetric outcome (Statistical analysis): Data was analyzed by computer using SPSS version 20, Chi square and Fisher's exact tests were used to compare the two groups. $\mathrm{P} \leq 0.05$ was considered to indicate significance and $\mathrm{P}$ $\leq 0.001$ was considered to indicate high significance. Univariate and multivariate regression analysis was used to assess the association between poor obstetric and maternal risk factors with the results were expressed as odds ratios (OR) with $95 \%$ confidence intervals $(\mathrm{CI})$. The value $\mathrm{P} \leq 0.05$ was treated as statistically significant.

\section{Results}

There was no significant difference between the three groups regarding age, parity, body mass index and family history of CKD ( $>0.05)$. Patients with late stage CKD have longer duration of the disease $>5$ years, higher baseline serum creatinine, higher rate of pelvicalyceal dilatation on renal ultrasound, higher rate of initial hypertension with intake of more than two antihypertensive drugs, higher rate of initial proteinuria and more frequent antenatal care visits $>6$ when compared to those with early stage CKD $(\mathrm{p}<0.001)$ as depicted in Table 1. 
There was no significant difference between the three groups regarding age, parity, body mass index and family history of CKD $(p>0.05)$. Patients with late stage CKD have longer duration of the disease $>5$ years, higher baseline serum creatinine, higher rate of pelvicalyceal dilatation on renal ultrasound, higher rate of initial hypertension with intake of more than two antihypertensive drugs, higher rate of initial.

Table 1. Maternal characteristics.

\begin{tabular}{|c|c|c|c|c|c|}
\hline & $\begin{array}{l}\text { Early } \\
\text { stage } \\
\text { CKD } \\
(n=286)\end{array}$ & $\begin{array}{l}\text { Late } \\
\text { stage } \\
\text { CKD } \\
(n=204)\end{array}$ & $\begin{array}{l}\text { Control } \\
\text { group } \\
(n=200)\end{array}$ & $\begin{array}{l}\text { Chi } \\
\text { square } \\
\text { test }\end{array}$ & P-value \\
\hline \multicolumn{6}{|l|}{ Age: } \\
\hline $20-30$ years & 136 & 112 & 106 & \multirow{2}{*}{2.9} & \multirow{2}{*}{0.23} \\
\hline$>30$ years & 150 & 92 & 94 & & \\
\hline \multicolumn{6}{|l|}{ Parity: } \\
\hline Nullipara & 144 & 114 & 108 & \multirow{2}{*}{1.57} & \\
\hline Multipara & 142 & 90 & 92 & & 0.46 \\
\hline \multicolumn{6}{|l|}{$\begin{array}{l}\text { Body mass index } \\
\text { at inclusion: }\end{array}$} \\
\hline Average $\quad(20-25$ & & & & \multirow{4}{*}{4.33} & \\
\hline $\left.\mathrm{Kg} / \mathrm{m}^{2}\right)$ & 146 & 122 & 116 & & \\
\hline Overweight \& & & & & & \\
\hline Obese $\left(>25 \mathrm{Kg} / \mathrm{m}^{2}\right)$ & 140 & 82 & 84 & & 0.11 \\
\hline $\begin{array}{l}\text { Family history of } \\
\text { CKD }\end{array}$ & 18 & 20 & 12 & 2.83 & 0.24 \\
\hline $\begin{array}{l}\text { Criteria of Renal } \\
\text { disease: }\end{array}$ & & & & & \\
\hline \multicolumn{6}{|l|}{ Duration of $C K D$} \\
\hline$<5$ years & 204 & 112 & - & \multirow[t]{2}{*}{13.3} & \multirow[t]{2}{*}{$<0.001$} \\
\hline$\geq 5$ years & 82 & 92 & - & & \\
\hline \multicolumn{6}{|l|}{$\begin{array}{l}\text { Baseline } \\
\text { Creatinine }\end{array}$} \\
\hline$\leq 1.4$ & 286 & 26 & - & 388.2 & $<0.001$ \\
\hline $1.5-3$ & 0 & 156 & - & 317.3 & $<0.001$ \\
\hline$\geq 3$ & 0 & 22 & - & 29.8 & $<0.001$ \\
\hline $\begin{array}{l}\text { Pelvicalyceal } \\
\text { dilatation }\end{array}$ & 18 & 68 & - & 58.3 & $<0.001$ \\
\hline \multicolumn{6}{|l|}{ Initial } \\
\hline $\begin{array}{l}\text { Number anti- } \\
\text { hypertensive } \\
\text { drugs }\end{array}$ & & & & & \\
\hline$\leq 2$ & 22 & 102 & - & 110.5 & $<0.001$ \\
\hline$>2$ & 0 & 70 & - & 111.7 & $<0.001$ \\
\hline $\begin{array}{l}\text { Antenatal care } \\
\text { visits }\end{array}$ & 196 & 54 & - & 82.6 & $<0.001$ \\
\hline$<6$ & 90 & 150 & - & & \\
\hline$\geq 6$ & 0 & 52 & - & 78.9 & $<0.001$ \\
\hline
\end{tabular}

\begin{tabular}{|lllll|}
\hline $\begin{array}{l}\text { Initial Proteinuria } \\
\text { Systemic disease }\end{array}$ & 72 & 84 & 13.3 & $<0.001$ \\
\hline \begin{tabular}{l} 
Diabetes mellitus \\
\hline Systemic lupus
\end{tabular} & 46 & & & \\
\hline $\begin{array}{l}\text { erythematosus } \\
\text { eKD=Chronic kidney disease }\end{array}$ & 38 & \\
\hline \begin{tabular}{l} 
CKD \\
\hline
\end{tabular}
\end{tabular}

Patients with CKD were more prone to experience deterioration of kidney function, obstetric hemorrhage (miscarriage, antepartum and postpartum hemorrhage), anemia, gestational hypertension, preeclampsia, repeated hospital admissions, delivery by cesarean section, recurrent urinary tract infections, blood transfusion and admission to ICU compared to control group ( $\mathrm{p}<0.001)$ as shown in Table 2 .

Table 2. Maternal outcome.

\begin{tabular}{|c|c|c|c|c|c|}
\hline & $\begin{array}{l}\text { Early } \\
\text { stage } \\
\text { CKD } \\
(n=286)\end{array}$ & $\begin{array}{l}\text { Late } \\
\text { stage } \\
\text { CKD } \\
(n=204)\end{array}$ & $\begin{array}{l}\text { Control } \\
\text { group } \\
(n=200)\end{array}$ & $\begin{array}{l}\text { Chi } \\
\text { square } \\
\text { test }\end{array}$ & P-value \\
\hline $\begin{array}{l}\text { Deterioration of } \\
\text { kidney function }\end{array}$ & 66 & 184 & $4^{*}$ & 377.3 & $<0.001$ \\
\hline \multicolumn{6}{|l|}{$\begin{array}{l}\text { Obstetric } \\
\text { hemorrhage: }\end{array}$} \\
\hline -Miscarriage & 92 & 88 & 22 & 52.3 & $<0.001$ \\
\hline $\begin{array}{l}\text {-Antepartum } \\
\text { hemorrhage }\end{array}$ & 34 & 46 & 18 & 17.4 & $<0.001$ \\
\hline $\begin{array}{l}\text {-Postpartum } \\
\text { hemorrhage }\end{array}$ & 28 & 48 & 12 & 31.7 & $<0.001$ \\
\hline \multicolumn{6}{|l|}{$\begin{array}{l}\text { Medical } \\
\text { complications: }\end{array}$} \\
\hline $\begin{array}{l}\text {-Anemia } \quad(\mathrm{Hb}<11 \\
\mathrm{gm} \%)\end{array}$ & 58 & 92 & 22 & 68.4 & $<0.001$ \\
\hline $\begin{array}{l}\text {-Gestational } \\
\text { hypertension }\end{array}$ & 66 & 108 & 18 & 102.5 & $<0.001$ \\
\hline $\begin{array}{l}\text { Development of } \\
\text { Preeclampsia }\end{array}$ & 42 & 72 & 12 & 62.2 & $<0.001$ \\
\hline $\begin{array}{l}\text { Repeated } \\
\text { hospital } \\
\text { admissions } \quad(>3 \\
\text { times) }\end{array}$ & 36 & 98 & 8 & 138.9 & $<0.001$ \\
\hline \multicolumn{6}{|l|}{ Mode of delivery: } \\
\hline -Vaginal & 78 & 40 & 92 & 35.5 & $<0.001$ \\
\hline -Vacuum & 66 & 32 & 36 & 4.52 & $<0.001$ \\
\hline -Cesarean section & 142 & 122 & 72 & 23.08 & $<0.001$ \\
\hline Recurrent UTIs & 64 & 132 & 18 & 163.5 & $<0.001$ \\
\hline $\begin{array}{l}\text { Blood } \\
\text { transfusion }\end{array}$ & 32 & 96 & 12 & 130.3 & $<0.001$ \\
\hline Admission to ICU & 28 & 82 & 6 & 117.1 & $<0.001$ \\
\hline Mortality & 0 & 0 & 0 & - & - \\
\hline
\end{tabular}


Citation: Elkilani O, Gaber W, Hamza H, et al.. Predictors of poor obstetric outcome among women with chronic kidney disease: A five-year observational study.. J Preg Neonatal Med 2018;2(1):5-9.

"Fischer's exact test, UTI=Urinary tract infection, ICU=Intensive care unit.

Infants of mothers with CKD were more prone to develop intrauterine fetal demise, low birth weight $(<2.5 \mathrm{~kg})$, prematurity ( $<37$ weeks), low Apgar score ( $<7$ at 5 minutes), admission to NICU, need for assisted ventilation and neonatal mortality compared to control group $(\mathrm{p}<0.001)$ as shown in Table 3 .

Table 3. Fetal and neonatal outcome.

\begin{tabular}{|c|c|c|c|c|c|}
\hline & $\begin{array}{l}\text { Early } \\
\text { stage } \\
\text { CKD } \\
(n=286)\end{array}$ & $\begin{array}{l}\text { Late } \\
\text { stage } \\
\text { CKD } \\
(n=204)\end{array}$ & $\begin{array}{l}\text { Control } \\
\text { group } \\
(n=200)\end{array}$ & $\begin{array}{l}\text { Chi } \\
\text { square } \\
\text { test }\end{array}$ & P-value \\
\hline $\begin{array}{l}\text { Intrauterine } \\
\text { fetal demise }\end{array}$ & 14 & 22 & $2^{*}$ & 18.9 & $<0.001$ \\
\hline $\begin{array}{ll}\text { Low } & \text { birth } \\
\text { weight } & \quad<2.5\end{array}$ & & & & & \\
\hline $\mathrm{Kg})$ & 56 & 108 & 14 & 121.2 & $<0.001$ \\
\hline $\begin{array}{l}\text { Prematurity } \\
\text { ( }<37 \text { weeks) }\end{array}$ & 66 & 94 & 16 & 78.5 & $<0.001$ \\
\hline $\begin{array}{l}\text { Low Apgar } \\
\text { score (<7 at } 5 \\
\text { minutes) }\end{array}$ & 76 & 128 & 10 & 161.9 & $<0.001$ \\
\hline $\begin{array}{l}\text { Admission to } \\
\text { NICU }\end{array}$ & 68 & 96 & 8 & 100.4 & $<0.001$ \\
\hline $\begin{array}{ll}\text { Need } & \text { for } \\
\text { assisted } & \\
\text { ventilation } & \end{array}$ & 34 & 72 & $2^{*}$ & 95.2 & $<0.001$ \\
\hline $\begin{array}{l}\text { Neonatal } \\
\text { mortality }\end{array}$ & 20 & 46 & $0^{*}$ & 63.1 & $<0.001$ \\
\hline
\end{tabular}

*Fischer's exact test, NICU=Neonatal intensive care unit.

Stage of $\mathrm{CKD} \geq 2(\mathrm{OR}=2.33, \mathrm{CI}=1.26-3.96)$, duration of $\mathrm{CKD}$ $\geq 5$ years $(\mathrm{OR}=0.69, \mathrm{CI}=0.53-0.98)$, baseline creatinine $1.5-3$ $\mathrm{Mg} / \mathrm{dL} \quad(\mathrm{OR}=2.14, \mathrm{CI}=1.34-3.44)$, baseline creatinine $>3$ $\mathrm{Mg} / \mathrm{dL}(\mathrm{OR}=2.28, \mathrm{CI}=1.17-4.05)$, pelvicalyceal dilatation on renal ultrasound $(\mathrm{OR}=1.49, \quad \mathrm{CI}=1.22-2.85)$, initial Hypertension $(\mathrm{OR}=4.11, \mathrm{CI}=1.71-9.85)$, intake of more than two anti-hypertensive drugs $(\mathrm{OR}=1.75, \quad \mathrm{CI}=1.28-3.88)$, antenatal care visits $<6 \quad(\mathrm{OR}=1.99, \mathrm{CI}=1.45-2.76)$, initial proteinuria $(\mathrm{OR}=2.23, \quad \mathrm{CI}=1.99-2.89), \quad$ development of preeclampsia $(\mathrm{OR}=1.66, \mathrm{CI}=1.11-3.21)$, the presence of prenatal anemia $(\mathrm{OR}=0.14, \mathrm{CI}=0.02-0.25)$ and the presence of underlying systemic disease $(\mathrm{OR}=3.08, \mathrm{CI}=2.04-4.65)$ were strong predictors of poor obstetric outcome in patients with CKD as depicted in Table 4.

Table 4. Predictors of poor obstetric outcome by univariate and multivariate regression analyses.

\begin{tabular}{llll}
\hline Risk factors & $\begin{array}{l}\text { Odds } \\
\text { Ratio (OR) }\end{array}$ & $\mathbf{P}$-value & $\begin{array}{l}\mathbf{9 5 \%} \\
\text { Interval }\end{array}$ \\
\hline Stage of CKD $\geq \mathbf{2}$ & 2.33 & $<0.001$ & $1.26-3.96$ \\
\hline $\begin{array}{l}\text { Duration of CKD } \geq \mathbf{5} \\
\text { years }\end{array}$ & 0.69 & 0.02 & $0.53-0.98$ \\
\hline Baseline Creatinine & & &
\end{tabular}

\begin{tabular}{|c|c|c|c|}
\hline $1.5-3$ & 2.14 & 0.007 & $1.34-3.44$ \\
\hline$>3$ & 2.28 & 0.002 & $1.17-4.05$ \\
\hline Pelvicalyceal dilatation & 1.49 & 0.005 & $1.22-2.85$ \\
\hline Initial Hypertension & 4.11 & 0.002 & $1.71-9.85$ \\
\hline $\begin{array}{l}\text { Number of anti- } \\
\text { hypertensive drugs }>2\end{array}$ & 1.75 & 0.04 & $1.28-3.88$ \\
\hline Antenatal care visits $<6$ & 1.99 & 0.008 & $1.45-2.76$ \\
\hline Initial Proteinuria & 2.23 & 0.01 & $1.99-2.89$ \\
\hline $\begin{array}{l}\text { Development } \\
\text { Preeclampsia }\end{array}$ & 1.66 & 0.02 & $1.11-3.21$ \\
\hline Prenatal Anemia & 0.14 & $<0.001$ & $0.02-0.25$ \\
\hline Systemic disease & 3.08 & $<0.001$ & $2.04-4.65$ \\
\hline
\end{tabular}

\section{Discussion}

The current study confirmed the previous data of poor obstetric outcome in patients with CKD even those with early stage-1 CKD with higher maternal risk of deterioration of kidney function, obstetric hemorrhage (miscarriage, antepartum and postpartum hemorrhage), anemia, gestational hypertension, preeclampsia, repeated hospital admissions, delivery by cesarean section, longer hospital stay $>3$ days after delivery, blood transfusion and admission to ICU, as well as higher fetal risk of intrauterine fetal demise, low birth weight, prematurity, low Apgar score at 5 minutes, admission to NICU, need for assisted ventilation and neonatal mortality.

A recent retrospective study comparing pregnant women with and without CKD with 778 women in every group revealed $52 \%$ increased odds of preterm delivery, 33\% increased odds of delivery by cesarean section, $71 \%$ increased odds of admission to NICU and 2-fold increased odds of low birth weight in patients with CKD [7].

Also, pregnancy with CKD had greater odds of preeclampsia (odds ratio [OR], 10.36; 95\% confidence interval [95\% CI], 6.28 to 17.09 ), premature delivery (OR, 5.72; 95\% CI, 3.26 to 10.03), small for gestational age/low birth weight (OR, 4.85; 95\% CI, 3.03 to 7.76), cesarean section (OR, 2.67; 95\% CI, 2.01 to 3.54 ), and failure of pregnancy (OR, 1.80; 95\% CI, 1.03 to 3.13 ) as demonstrated in a recent systematic review and meta-analysis [8].

Even patients with stage-1 CKD with e GFR ranging between $60-89 \mathrm{ml} / \mathrm{min} / 1.73 \mathrm{~m}^{2}$ were more prone to significant maternal and fetal complications as reported by a previous study [9].

A retrospective series of 87 women with CKD found that those who initially had moderate renal impairment had a $40 \%$ risk of a decline in renal function during pregnancy, which persisted after birth in about half of the affected patients [10].

In this study, higher stage of CKD Stage $\geq 2$, duration of CKD 5 years, higher baseline creatinine, pelvicalyceal dilatation on renal ultrasound, initial Hypertension, administration of more than two anti-hypertensive drugs, antenatal care visits $<6$, initial proteinuria, development of preeclampsia, the presence 
of prenatal anemia and the presence of underlying systemic disease were strong predictors of poor obstetric outcome in patients with CKD.

Patients with early stage CKD with eGFR 60-89 $\mathrm{ml} / \mathrm{min} / 1.73$ $\mathrm{m}^{2}$ were not at increased risk for preeclampsia, small for gestational age or preterm birth unless they were also hypertensive as reported by previous population-based study in Norway [11].

The risk for adverse pregnancy rises in later stages of CKD with the presence of hypertension and proteinuria were found to be independent risk factors in a previous prospective study [12].

A more recent prospective study comparing pregnancy outcomes of 504 pregnancies in women with CKD to 836 lowrisk pregnancies revealed increased risk of adverse pregnancy outcome across CKD stages with stage 1 CKD remained associated with adverse pregnancy outcomes even in the absence of baseline hypertension, proteinuria, or systemic disease [13]

The strength of this study resides in being prospective with adequate number of patients presented in the first trimester with availability of baseline renal function tests, standard hospital protocol for management and low number of drop out cases.

Inability to extend the period of follow up beyond the puerperium as well as to conduct a multicenter study constitutes unintended limitation of the current study.

Future research should focus on optimization and correction of maternal risk factors to improve obstetric outcome in patients with CKD.

\section{Conclusion}

Patients with CKD even those in the early stage suffered from poor maternal and fetal outcome. Many risk factors other than hypertension, proteinuria and underlying systemic disease were identified as predictors of poor obstetric outcome.

\section{Acknowledgements}

The authors would like to acknowledge the contribution of the residents and nursing staff of the outpatient clinics of the Internal Medicine department and delivery ward of Menoufia University Hospital.

\section{Disclosure Statement}

No potential conflict of interest was reported by the authors.

\section{References}

1. Fischer MJ, Lehnerz SD, Hebert JR, et al. Kidney disease is an independent risk factor for adverse fetal and maternal outcomes in pregnancy. Am J Kidney Dis. 2004;43:415-23.
2. Imbasciati E, Gregorinin G, Cabiddu G, et al. Pregnancy in CKD stages 3 to 5: fetal and maternal outcomes. Am J Kidney Dis. 2007;49:753-62.

3. Hou S. Historical perspective of pregnancy in chronic kidney disease. Adv Chronic Kidney Dis. 2007;14:116-8.

4. Williams D, Davison J. Chronic kidney disease in pregnancy. BMJ. 2008;336:211-5.

5. Piccoli GB, Attini R, Vasario E, et al. Pregnancy and chronic kidney disease: A challenge in all CKD stages. Clin J Am Soc Nephrol. 2010;5:844-55.

6. Nevis IF, Reitsma A, Dominic A, et al. Pregnancy outcomes in women with chronic kidney disease: A systematic review. Clin J Am Soc Nephrol. 2011;6:2587-98.

7. Kendrick J, Sharma S, Holmen J, et al. Kidney disease and maternal and fetal outcomes in pregnancy. Am J Kidney Dis. 2015;66:55-9.

8. Zhang JJ, Ma XX, Hao L, et al. A Systematic Review and Meta-Analysis of Outcomes of Pregnancy in CKD and CKD Outcomes in Pregnancy. Clin J Am Soc Nephrol. 2015;10:1964-78.

9. Alsuwaida A, Mousa D, Al-Harbi A, et al. Impact of early chronic kidney disease on maternal and fetal outcomes of pregnancy. J Matern Fetal Neonatal Med. 2011;24:1432-6.

10. Jones DC, Hayslett JP. Outcome of pregnancy in women with moderate or severe renal insufficiency. $\mathrm{N}$ Engl J Med. 1996;335:226-32.

11. Munkhaugen J, Lydersen S, Romundstad PR, et al. Kidney function and future risk for adverse pregnancy outcomes: a population-based study from HUNT II, Norway. Nephrol Dial Transplant. 2009;24:3744-50.

12. Piccoli GB, Fassio F, Attini R, et al. Pregnancy in CKD: whom should we follow and why. Nephrol Dial Transplant. 2012;27:111-8.

13. Piccoli GB, Cabiddu G, Attini R, et al. Risk of Adverse Pregnancy Outcomes in Women with CKD. J Am Soc Nephrol. 2015;2:2011-22.

\section{*Correspondence to}

Osama Elkilani

Department of Obstetrics and Gynecology

Menoufia University

Egypt

E-mail: oelkilani@yahoo.com 